\title{
The Superiority Value of a Poetry Anthology in Providing Public Awareness of The Environment During Covid-19 Pandemic
}

\author{
Satryo Kusuma Wibowo $^{l^{*}}$, Iriyanto Widisuseno ${ }^{2}$ \\ ${ }^{1}$ Master of Literature, Faculty of Humanities, Diponegoro University \\ ${ }^{2}$ Professor of Philosophy, Faculty of Humanities, Diponegoro University
}

\begin{abstract}
This study describes the superiority value of a poetry anthology in providing public awareness of the environment during the Covid-19 pandemic. Sources of data in this study were four poems from the poetry anthology "Covid-19, Radang dan Ladang Kehidupan". The four poems have the theme of public awareness of the environment during the Covid-19 pandemic. The data was collected using a qualitative method and analyzed data with the stages of identifying, classifying, interpreting, discussing, and concluding the data. The theory used is the theory of ecocriticism. The results show that the values in the poetry anthology have their advantages in conveying messages to the public regarding environmental awareness. The interpretation of the values in the poem implies that the Covid-19 pandemic is a consequence for people who cannot properly care for the environment. On the other hand, Covid-19 has also become a momentum to make people aware so that they can be wiser when living side by side with nature and the surrounding environment.
\end{abstract}

\section{Introduction}

Currently Currently, the Covid -19 pandemic has entered the world order of life. Day after day, the cases are increasing. The negative impact caused by the covid-19 pandemic has made governments around the world try to take various kinds of preventive measures, including social and physical distancing [1]. This policy is ultimately able to change the habits or lifestyle of the world community. Community activities are now mainly carried out at home, the use of transportation means is also limited. Thus, the pollution caused through transportation and industrial activities is decreasing. This is certainly able to provide positive changes for the environment, human health and the surrounding ecosystem. For example, the $\mathrm{CO} 2$ emissions in China have decreased by $25 \%$ in just two weeks after China started selfquarantine [2]. In line with that, Borage [3] said that the lack of human activity could bring changes in nature and the environment for the better. It can even be predicted that nature will recover if conditions like this continue. The Covid -19 pandemic is a warning for the public to be aware and willing to compromise with the surrounding environmental conditions because indirectly, humans have a significant role in the sustainability of the environment.

* Corresponding author: satryokusumawibowo07@gmail.com 
Moreover, the mass media only conveys data on victims who have contracted Covid-19 and conveys appeals for preventive measures [4].

In other words, there are not many media that educatively convey the role of Covid-19 in building public awareness of the environment. Through a poetry anthology entitled "Covid 19, Radang dan Ladang Kehidupan" trying to understand society related to Covid -19, especially in building awareness to care for the environment. The poetry anthology itself is a book that contains a collection of poems that have the same topic. The poetry contained in poetry anthologies can be an effective medium to convey a message to the reader. Today's society has little free time to read, and the most suitable media are short works such as poetry and short stories [5]. As a literary work, poetry can be a means of communication between the author and the reader. In the communication process, the author acts as the sender of the message while the reader receives the message. The medium communicated in poetry is objective data and includes subjective data in the form of the author's attitudes, feelings, and imagination [6]. Another view [7] apart as an information medium of poetry can also be a tool to convey an idea to the public society. The language style is poetic and aesthetic nature makes poetry able to persuade the reader to enter the world situation with all the contents of the message created by the poet. In addition, poetry has a moral message that can give readers a meaningful impression so that the reader can easily absorb the values contained in the poetry theme. In line with that, Dominic [5] said that poetry is the best medium to instil social and moral values into readers minds. Based on the explanation above, this research will describe the superior value of poetry anthology in providing public awareness of the environment during the Covid-19 pandemic.

Furthermore, to dissect the relationship between poetry anthology and public awareness of the environment, a relevant theoretical approach is needed. Glotfelty and Fromm [8] said that the ecocritical approach is appropriate for seeing the relationship between humans and the environment. Most of the ecocritical works have the same motivation, namely to build awareness that the phenomenon of environmental damage has reached its limit and that it is a consequence of human action. Ecocritical tries to offer a genuinely transformative discourse to analyze and criticize environmental conditions through literary works to increase people's attention to the environment [9].

\section{Method}

This research uses qualitative research and content analysis. Creswell [10] said qualitative research relies on text and image data as material objects. Therefore, this study will focus on content analysis in a literary text. The data sources used were four poems in the poetry anthology" Covid-19, Radang dan Ladang kehidupan". The four poems share a common theme, namely public awareness of the environment during the Covid-19 pandemic. The data has been collected by analyzed in the following steps: (1) Identifying the data, namely looking at the value contained in the poetry anthology related to public awareness of the environment during the Covid-19 pandemic, (2) Classifying by summarizing the sections of poetry that have the value of public awareness of the environment during the Covid-19 pandemic, (3) interpret of classified poetry content, and (4) Discuss and conclude the results of the analysis. 


\title{
3 Result and Discussion
}

The public to be aware of the environment. Anthology of Poetry can be an alternative media to educate the public about belonging awareness of the environment. In the anthology, there is a collection of poetry that varies in content and style of delivery so that readers do not get bored of reading it, and readers can choose which poetry they like and understand. To show more clearly the advantages of the poetry anthology, it is necessary to examine the poems contained in the anthology, in this case, four poems originating from the poetry anthology "Covid-19 Radang and Ladang Hidup".

\subsection{What happened}

"Teeth are not brushed.

Bodies do not bathe.

Humans do not die.

What will happen?"

Likewise in the world the

The world is not clean.

What happened?

The current atmosphere, corona

Cleanse the world from pollution

Caused by human activity" [11].

To create a stable natural condition, everything must be renewed and maintained. The author implicitly makes an analogy between natural conditions and everyday life, what happens when the body is not cleansed, and what happens if the human population is not suppressed. Of course, with a simple analogy, the writer tries to provide understanding to ordinary readers. The presence of Covid-19 is a tool to clean the world from pollution caused by humans themselves. Like teeth will be damaged, hollow and cragged if not brushed, the body will smell, get dirty and cause disease if you do not shower. Likewise, what will happen to Earth when humans do not care for it? The Earth will be damaged and cause environmental instability. The Covid-19 phenomenon warns humankind, who seems to have forgotten to care for the environment. Dermawan [12] said that the human population is geometrically growing rapidly; while the land is experiencing erosion, forest decline, and pollution that threatens the environment, today's society is only pursuing economic needs without paying attention to environmental conditions.

\subsection{The Crown}

\author{
"That's right, about Earth \\ Today being freed \\ From the noise and pollution \\ of industrial waste \\ From anger and greed. \\ The air breathes freely \\ The sky returns to find its blue color the \\ Sea smiles clearly. The \\ Wound of the ozone hole is faintly closing. \\ The Universe was amazed by the Crown, \\ "Thank you, Corona" [11].
}


In the poem "The Crown", there is an insinuation against people indifferent to the environment. Physical distancing regulations limit the community's space for movement. This results in a drastic reduction of the pollution that is usually caused by vehicles and industrial activities. Of course, this has a positive influence on the earth's environment. Globally, vehicles and industrial waste have a significant impact on environmental pollution [13]. The covid-19 pandemic is considered a boon for the Earth. Indirectly, this poem wants to prove that humans are most responsible for environmental damage. Straightforward language becomes sarcasm for people who do not care about the environment.

\title{
3.3 Chanting of the Universe
}

\author{
"There was a time \\ When everything looked beautiful and perfect the \\ Earth was inhabited and the sky was so bright \\ Little boys running after time \\ As the giver of knowledge awaits at the school gate \\ And over and over and over and over \\ Until the universe gets bored \\ With the story of the inhabitants of the earth who are not wise in fighting \\ And let the corona wipe out all the stories \\ "[11].
}

This poem describes a series of events that occurred after the Covid-19 pandemic. During school, the community was always taught to be able to care for the environment properly. However, in the end, people still ignore the environment. This phenomenon seems to be a cycle in people's lives. The Covid -19 pandemic is here to break this cycle. Through its impact, Covid-19 reminds people to return to following the teachings that people received about the environment when they were still in school. Silent, lonely, and willing conditions illustrate human resignation to the conditions experienced during the Covid-19 pandemic. This poetry coherently invites the public to look at flashbacks, forming regret into an awareness.

\subsection{Sign What}

"Only you know the mystery.

Even though people say it's a pandemic and an epidemic.

I don't know the unknown.

Maybe this is a symbol of showing.

We are no longer friends on earth.

Often playing fake dramas that are not genuine,

Oh Allah.we still ask for forgiveness.

All mistakes and mistakes cannot be counted. "[11].

The pandemic is Covid -19able to destroy society's way of life, making people wonder how and why this virus can exist. Until it concludes that man is the mastermind behind all these conditions, this poem invites its readers to reflect on the current condition of Covid -19 and its relationship to the natural environment. Through an afterthought, readers can find different perspectives. If all this time people have misbehaved towards nature, then change their behaviour patterns, both thoughts, and actions for the better.Furthermore, there is an intense climax at the end of the poem, the result of an afterthought is manifested in the recitation of a prayer presented in the poem. Prayer alone can arouse awareness, regret and 
gain inner peace in the face of all the given trials. Indirectly, the poem entitled "The Sign of What" invites people to be aware of the environment through spirituality and religiosity approaches. Religious communities view Covid-19 as a form of reprimand and a test that must be passed [14].

\section{Conclusion}

Based on the above discussion, it can be concluded that the excellence value of poetry anthology lies in its fundamental nature, namely in the form of a collection of varied poems, packaged in imaginative language, each of which has a rhythm, lyrics, and rhyme which are composed of solid and meaningful words. Thus, poetry has adequate persuasion power in educating the public during the Covid-19 pandemic to care for the environment and build a healthy and clean lifestyle. Anthology readers are not easily bored because, in the poetry anthology, various kinds of poetry have varied messages and aesthetics, which does not seem monotonous. In addition, there are several same themes in the poetry anthology so that readers will remain focused on the topic the author wants to convey. Of the four poems that have been discussed, each of them has a superior value in conveying messages and ideas. Be it in terms of literary aesthetics, language style, creativity, and objectivity in providing the reality of the Covid-19 pandemic. Furthermore, the four poems also fulfil ecocritical elements in which there is a relationship between humans and the environment. In general, the four poems describe that society is responsible for environmental damage on earth. With the Covid-19 pandemic, humans should be aware of and want to care for the environment.

\section{References}

1. M. E. David, J. A Robert, Int J. Environ. Res. Public Health, 18, 3 (2021)

2. M. E. Zowalaty, S. G. Young, J. D. Jarhult, J. Inf Eco Env, 10, 15 (2020)

3. S. Borage, P. Shelotkar, J. Res Phar Science, 11, 235 (2020)

4. D. Indiyanti, H. N. Khusnia, S. Khotijah, U. Mataram, J. Media Com, 3, 41 (2020)

5. K. V. Dominick. Greetings from the Vice-Chancellor, 12, 25 (2020)

6. H. Mahliatussikah, Pembelajaran Puisi, (Universitas Negeri Malang, Malang, 2015)

7. M. Harun, Pembelajaran Puisi untuk Mahasiswa, (Syiah Kuala University Press, Aceh, 2018)

8. C. Glotvelty, H. Fromm, The Ecocriticism Reader, (The University of Georgia Press, Athens and London, 1996)

9. G. Garrard, Ecocriticism, (Taylor and Francis e-Library, New York, 2004)

10. J. W. Creswell, J. D. Creswell, Research design : Qualitative, quantitative, and mixed methods approaches, (Sage Publications, Los Angeles, 2018)

11. S. Covid-1, Antologi Puisi : Covid-19 Radang dan Ladang Kehidupan, (Pustaka Abadi, Jember, 2020)

12. M. Dermawan, J. Legislasi Ind, 6, 74 (2009)

13. A. J. Budiyono, Dirgantara, 2, 21 (2010)

14. M. Muslim, J. Man Bisnis, 23, 11 (2020) 